Research Article

\title{
Effect of honey on hepatotoxicity induced by antitubercular drugs in albino rats
}

\author{
Rakhamaji D. Chandane*, Jugalkishor B. Jaju, Manik S. Ghadlinge, Rama R. Bhosale, \\ Ajay R. Chandrakapure
}

Department of Pharmacology, Swami Ramanand Teerth Rural Govt. Medical College, Ambajogai, District- Beed, Maharashtra 431517, India

Received: 22 January 2013 Accepted: 27 January 2013

*Correspondence to: Dr. Rakhamaji D. Chandane, Email:

drchandanerd@rediffmail.com

(C) 2013 Chandane RD et al. This is an open-access article distributed under the terms of the Creative Commons Attribution License, which permits unrestricted use, distribution, and reproduction in any medium, provided the original work is properly cited.

\begin{abstract}
Background: Drug-induced hepatotoxicity is a potentially serious adverse effect of antituberculosis treatment (ATT) regimens containing isoniazid, rifampicin and pyrazinamide. Many in vitro and in vivo studies revealed that honey possess antioxidant property and hepotoprotective property but there is no systematic work available to test the effect of honey on antitubercular drugs induced hepatotoxicity in rats. Hence present study was carried out to explore the prophylactic and therapeutic effect of honey with its antioxidant activity against hepatotoxicity induced by antitubercular drugs (Isoniazid, Rifampicin and Pyrazinamide) in albino rats.

Methods: Hepatotoxicity in rats treated with antitubercular drugs (Isoniazid, Rifampicin and Pyrazinamide) was studied by assessing parameters such as Serum alanine aminotransferase (ALT), Serum aspartate aminotransferase (AST), Serum total protein, Serum Malondialdehyde (MDA) and Serum Superoxide dismutase activity (SOD). The effect of Honey as co-administration and administration after establishment of hepatotoxicity on above parameter was investigated. These biochemical observations were supplemented by Histopathological examination of liver.

Results: Honey significantly reversed changes in serum levels of AST, ALT, MDA, SOD, total protein and also histopathological changes produced by Antitubercular drugs. It was found that honey significantly prevented as well as reversed Antitubercular drugs induced hepatotoxicity and antioxidant activity. Conclusions: The results of present study show that honey has significant prophylactic and therapeutic value against antitubercular drugs induced hepatotoxicity.
\end{abstract}

Keywords: Honey, Hepatotoxicity, Antioxidant, Antitubercular drugs

\section{INTRODUCTION}

Liver plays a major role in the detoxification and excretion of many endogenous and exogenous compounds; any type of injury (due to systemic drugs, food preservatives, agrochemicals and addiction to alcohol) or impairments of its functions may lead to many complications in one's health. ${ }^{1}$ Tuberculosis is a common problem in India and worldwide, especially after the recent increase in incidence of acquired immunodeficiency syndrome (AIDS). Tuberculosis is communicable disease and spread easily among people. Drug-induced hepatotoxicity is a potentially serious adverse effect of antituberculosis treatment (ATT) regimens containing isoniazid, rifampicin and pyrazinamide. A higher risk of hepatotoxicity has been reported in Indian patients than in their Western counterparts. $^{2}$ The Antitubercular drugs induced hepatotoxicity is found to be mediated through oxidative damage and free radical damage to hepatocytes. ${ }^{3}$

Honey has had a valued place in traditional medicine for centuries and was used by Egyptians, Assyrians, Chinese, Greeks and Romans for wounds and diseases of gut. In ayurveda, honey (Madhu) is considered highly nutritious and of medicinal value for dissolving phlegm, reducing effects of poisons, treating urinary tract disorders, worm infestations, cough, diarrhea, for cleansing and healing wounds and many more health benefits. ${ }^{4}$ Honey possesses many properties and extensively studied for 
antibacterial activity, ${ }^{4,5}$ antifungal activity, wound healing property, burn healing property, indolent skin ulcer healing property, gastroenteritis, gastric ulcer ${ }^{6}$ and in many skin diseases.

Many in vitro and in vivo studies revealed that honey possess antioxidant property. ${ }^{8}$ There are many studies showing hepotoprotective property ${ }^{9,10}$ of honey but there is no systematic work available to test the effect of honey on antitubercular drugs induced hepatotoxicity in rats. Hence present study was carried out to explore the effect of honey in albino rats on biochemical and histopathological changes associated with antitubercular drugs induced hepatotoxicity. This study was carried out to study the prophylactic and curative value of honey with its antioxidant activity in antitubercular drugs induced hepatotoxicity in albino rats.

\section{METHODS}

Animals: Healthy adult albino rats of either sex of Wistar strain weighing 200-250 g were used for study. They were kept on standard balanced diet and water ad libitum. The care and procedures adopted for the present investigation were in accordance with the approval of Institutional Animal Ethics Committee. Permission for conduction of study was taken from Institutional Ethics Committee.

Hepatotoxic drugs: The doses of antitubercular drugs (isoniazid $[\mathrm{H}]-27 \mathrm{mg} / \mathrm{kg} /$ day, rifampicin $[\mathrm{R}]-54$ $\mathrm{mg} / \mathrm{kg} /$ day, pyrazinamide [Z]-135 $\mathrm{mg} / \mathrm{kg} /$ day) were extrapolated from daily human dose using the conversion table based on body surface area. ${ }^{11}$ All the three drugs were obtained in powder form from Lupin Ltd., Aurangabad, India.

Honey: Honey (Manufactured by Dabur India Ltd.) Purchased from the market was used in dose of $5 \mathrm{~g} / \mathrm{kg} /$ day P.O. ${ }^{12}$

Study design: After 10 days adaptation period, the animals were divided into five groups. Each group consisted of six animals. The groups were treated as follows:

Group I: Vehicle control i.e. 2\% gum acacia orally daily for 30 days.

Group II: $(\mathrm{H}+\mathrm{R}+\mathrm{Z})$ suspension orally daily for 30 days.

Group III: $(\mathrm{H}+\mathrm{R}+\mathrm{Z})$ suspension + Honey $(5 \mathrm{~g} / \mathrm{kg})$ orally daily for 30 days.

Group IV: $(\mathrm{H}+\mathrm{R}+\mathrm{Z})$ suspension orally for 1 to 30 days + Honey $(5 \mathrm{~g} / \mathrm{kg})$ orally from day 31 to day 45 .

Group V: $(\mathrm{H}+\mathrm{R}+\mathrm{Z})$ suspension orally for 1 to 30 days + Honey $(5 \mathrm{~g} / \mathrm{kg})$ orally from day 31 to day 60 .

Blood samples of animals from groups I, II and III were taken on $30^{\text {th }}$ day, Group IV on $45^{\text {th }}$ day and Group V on $60^{\text {th }}$ day for liver function tests and antioxidant tests by cardiac puncture under ether anaesthesia and livers were removed for histopathological examination.
Assessment of liver damage: Biochemical investigationsSerum alanine aminotransferase (ALT) and serum aspartate aminotransferase (AST) were estimated by Reitman and Frankel Method. ${ }^{13}$ Serum total protein, Serum Malondialdehyde (MDA) and Serum Superoxide dismutase activity (SOD) were estimated by Biuret method, Pasha and Sadasivadu method ${ }^{14}$ and Marklund and Marklund method ${ }^{15}$ respectively.

Histopathological examination of liver: The liver tissues were dissected out and fixed in $10 \%$ formalin. The paraffin sections were prepared and stained with haematoxylin and eosin and examined microscopically for histopathological changes.

Results were statistically analyzed by using students unpaired ' $t$ ' test and All values are Mean \pm SD. Group II was compared with Group I and Group III, IV and V were compared with Group II. $\mathrm{P}<0.05$ was taken as significant.

\section{RESULTS}

Group II animals which received antitubercular drugs for 30 days showed significant fall in serum protein level and rise in the levels of serum ALT and AST as compared to control group (Table 1). The antioxidant serum enzyme level in antitubercular drugs treated group II showed a significant increase in Serum MDA, while a significant decrease in Serum SOD as compared to control group (Table 2). Co-administration of honey along with the antitubercular drugs (Group III) significantly prevented all these changes compared with group II.

Treatment with Honey for 15 days after withdrawal of antitubercular therapy (group IV, 45th day) significantly reversed levels of serum protein $(\mathrm{P}<0.05)$, serum ALT $(\mathrm{P}<0.001)$ and AST $(\mathrm{P}<0.05)$ as compared to antitubercular drugs treated group II (Table 1). The antioxidant serum enzyme level in group IV showed a significant decrease in Serum MDA $(\mathrm{P}<0.05)$, while a significant increase in Serum SOD $(\mathrm{P}<0.01)$ as compared to antitubercular drugs treated group II (Table 2). Treatment with Honey for 30 days after withdrawal of antitubercular therapy (group V, 60th day) significantly reversed $(\mathrm{P}<0.001)$ all these changes (Serum MDA, $\mathrm{P}<0.01)$ and were nearly normalized.

In the histopathological studies, the liver sections of rat treated with vehicle showed normal hepatic architecture (Figure 1). Administration of antitubercular drugs for 30 days to group II produced changes of degeneration, necrosis and fibrosis on histological examination of rat livers (Figure 2-4). Co-administration of honey along with antitubercular drugs and treatment with honey for 15 and 30 days after withdrawal of antitubercular therapy reversed histological changes like degeneration, necrosis and fibrosis. There was also evidence of regeneration (Figure 5 \& 6). 
Table 1: Effect of honey on serum ALT, serum AST and serum total Protein level in albino rats.

\begin{tabular}{|c|c|c|c|c|}
\hline $\begin{array}{l}\text { Groups } \\
n=6\end{array}$ & Treatment given & $\begin{array}{l}\text { Sr. ALT } \\
\text { (units/ml) }\end{array}$ & $\begin{array}{l}\text { Sr. AST } \\
\text { (units/ml) }\end{array}$ & $\begin{array}{l}\text { Sr. Total } \\
\text { Protein(g/dl) }\end{array}$ \\
\hline I & Vehicle control & $37.93 \pm 2.41$ & $35.1 \pm 4.11$ & $7.78 \pm 0.20$ \\
\hline II & $\begin{array}{l}\text { ATD for } \\
30 \text { days }\end{array}$ & $\begin{array}{l}138.45 \pm 5.55 \\
\# \# \#\end{array}$ & $\begin{array}{l}73.04 \pm 2.01 \\
\# \# \#\end{array}$ & $\begin{array}{l}5.18 \pm 0.21 \\
\# \# \text { \# }\end{array}$ \\
\hline III & $\begin{array}{l}\text { ATD + Honey } \\
30 \text { days }\end{array}$ & $\begin{array}{l}70.88 \pm 2.26 \\
* *\end{array}$ & $\begin{array}{l}41.41 \pm 1.83 \\
* *\end{array}$ & $\begin{array}{l}6.67 \pm 0.29 \\
* * *\end{array}$ \\
\hline IV & $\begin{array}{l}\text { ATD For } 30 \text { day }+ \\
\text { Honey for next } 15 \\
\text { days }\end{array}$ & $\begin{array}{l}89.41 \pm 1.49 \\
* * *\end{array}$ & $\begin{array}{l}49.99 \pm 2.35 \\
*\end{array}$ & $\begin{array}{l}6.33 \pm 0.24 \\
*\end{array}$ \\
\hline $\mathrm{V}$ & $\begin{array}{l}\text { ATD For } 30 \text { day }+ \\
\text { Honey for next } 30 \\
\text { days }\end{array}$ & $\begin{array}{l}44.44+4.51 \\
* * *\end{array}$ & $\begin{array}{l}40.15 \pm 2.29 \\
* * *\end{array}$ & $\begin{array}{l}7.27 \pm 0.24 \\
* * *\end{array}$ \\
\hline
\end{tabular}

(All values are Mean \pm SD. Data was analyzed by using students unpaired ' $t$ ’ test); ATD- Antitubercular drugs; Sr. ALT= Serum alanine aminotransferase; $\mathrm{Sr}$. AST $=$ serum aspartate aminotransferase; $[\#, *=\mathrm{P}<0.05 ; \# \#, * *=\mathrm{P}<0.01 ; \# \# \#, * * *=\mathrm{P}<0.001]$

$\#=$ in comparison with Vehicle control group; $*=$ in comparison with ATD treated group

Table 2: Effect of honey on serum MDA and serum SOD level in albino rats.

\begin{tabular}{|c|c|c|c|}
\hline $\begin{array}{l}\text { Groups } \\
n=6\end{array}$ & Treatment given & $\begin{array}{l}\text { Sr. MDA } \\
\text { nmol/ml }\end{array}$ & $\begin{array}{l}\text { Sr. SOD } \\
\text { U/ml }\end{array}$ \\
\hline I & Vehicle control & $1.41 \pm 0.27$ & $11.93 \pm 0.64$ \\
\hline II & ATD for 30 days & $\begin{array}{l}3.65 \pm 0.31 \\
\# \# \#\end{array}$ & $\begin{array}{l}4.53 \pm 0.83 \\
\# \#\end{array}$ \\
\hline III & ATD + Honey 30 days & $\begin{array}{l}2.25 \pm 0.28 \\
* *\end{array}$ & $\begin{array}{l}9.33 \pm 0.79 \\
* * *\end{array}$ \\
\hline IV & $\begin{array}{l}\text { ATD For } 30 \text { day }+ \\
\text { Honey for next } 15 \text { days }\end{array}$ & $\begin{array}{l}2.51 \pm 0.28 \\
*\end{array}$ & $\begin{array}{l}8.27 \pm 0.70 \\
* *\end{array}$ \\
\hline $\mathrm{V}$ & $\begin{array}{l}\text { ATD For } 30 \text { day }+ \\
\text { Honey for next } 30 \text { days }\end{array}$ & $\begin{array}{l}2.16 \pm 0.31 \\
* *\end{array}$ & $\begin{array}{l}11.2 \pm 0.56 \\
* * *\end{array}$ \\
\hline
\end{tabular}

(All values are Mean \pm SD. Data was analyzed by using students unpaired't' test) ATD- Antitubercular drugs; Sr. MDA= serum Malondialdehyde; $\mathrm{Sr}$. SOD= serum Superoxide dismutase;

$$
[\#, *=\mathrm{P}<0.05 ; \quad \# \#, * *=\mathrm{P}<0.01 ; \# \# \#, * * *=\mathrm{P}<0.001]
$$

$\#=$ in comparison with Vehicle control group; $*=$ in comparison with ATD treated group

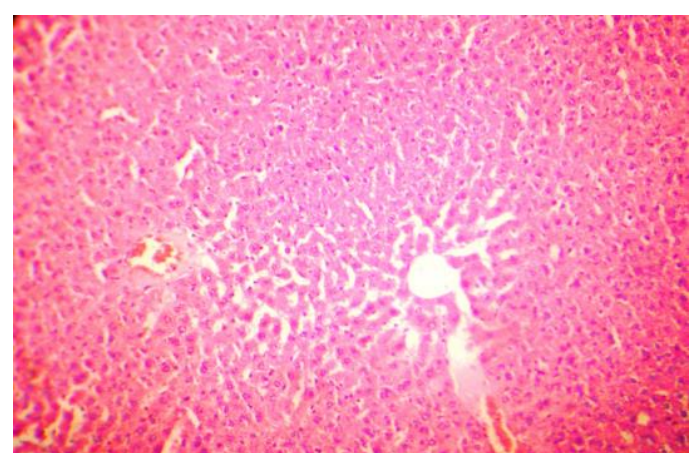

Figure 1: Liver sections of rat treated with vehicle showed normal hepatic architecture. 


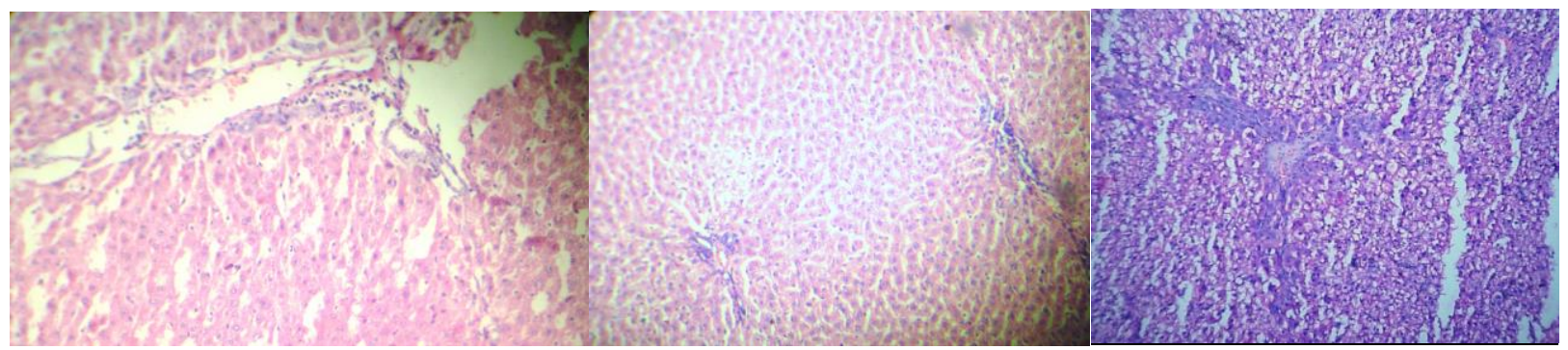

Figure 2-4: Administration of antitubercular drugs for 30 days to group II produced changes of degeneration, necrosis and fibrosis on histological examination of rat livers.

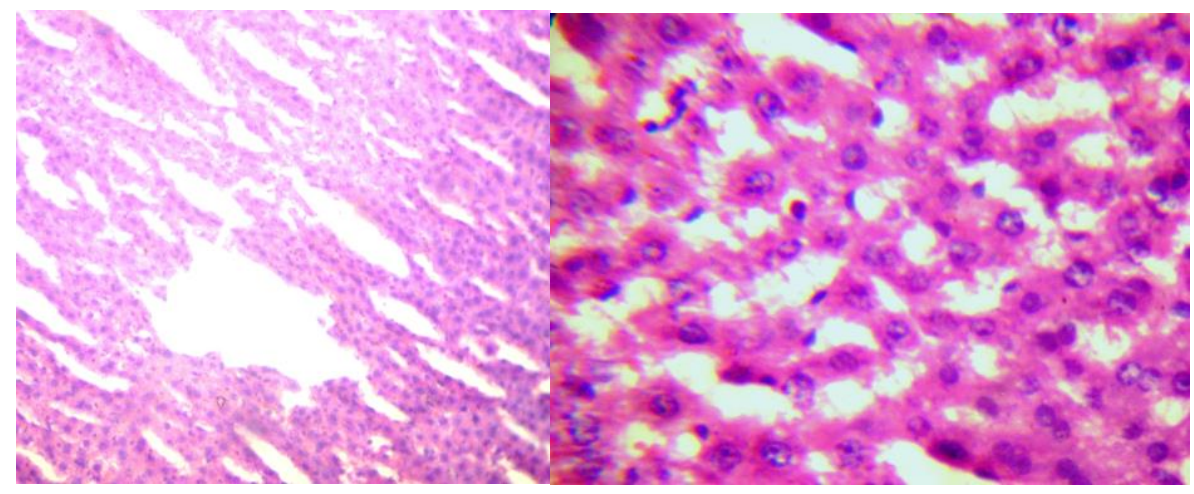

Figure 5-6: Reversal of histological changes.

\section{DISCUSSION}

The Antitubercular drugs induced hepatotoxicity is found to be mediated through oxidative stress and free radical damage to hepatocytes ${ }^{3} \mathrm{Sr}$. AST, Sr. ALT increases in hepatic damage due to leakage of enzymes from damaged hepatocytes into vascular compartment. Liver damage leads to decrease in synthetic capability leading to fall in serum protein levels. ${ }^{16}$ Rise of Sr. MDA due to ATD treatment may be attributed to the chronic pathology of liver leads to disturbances in circulation and oxygenation which in turn cause lipid peroxidation and subsequently increase Sr. MDA concentration. Therefore, lipid peroxidation may cause severe damage and play a key role in pathogenesis of several human diseases. Superoxide dismutase is an antioxidant enzyme which can destroy the superoxide anion, $\mathrm{O}_{2}^{-}$. This decrease in Sr. SOD activity could be due to the increased production of Reactive Oxygen Species as evident from the increased lipid peroxidation levels due to ATD treatment.

Liver biopsy is the most reliable index of liver damage. Liver damage is indicated by degeneration, necrosis and fibrosis while reduction in these parameters and evidence of regeneration are suggestive of hepatoprotection. ${ }^{16}$ Administration of antitubercular drugs also resulted in degeneration, necrosis and fibrotic changes in rat liver.

Concurrent administration of honey along with antitubercular drugs significantly prevented the rise in level of Serum Alanine Aminotransferase (ALT), Serum Aspartate Aminotransferase (AST) and serum Malondialdehyde (MDA). Similarly honey significantly prevented fall in serum total protein and Superoxide dismutase (SOD) as compared to group receiving antitubercular drugs alone. Administration of honey reduced degeneration, necrosis and fibrosis and shows regeneration.

Both 15 days and 30 days honey treatment given after induction of hepatotoxicity by antitubercular drugs significantly reversed the levels of Serum Alanine Aminotransferase, Serum Aspartate Aminotransferase, serum Malondialdehyde, serum total protein and Superoxide dismutase. But 30 days honey treatment reversed changes significantly to nearly normal level $(\mathrm{P}<0.001)$. Degeneration, necrosis and fibrosis reduced and regeneration increased in group treated with honey for 30 days.

Antioxidants can prevent cell damage due to the action of reactive oxygen species (ROS) and free radicals. ${ }^{17}$ Honey contains a variety of falconoid and phenolic acids, which act as antioxidants, scavenging and eliminating free radicals. The researchers found that consuming more honey increased the level of polyphenolic antioxidants in the blood. ${ }^{18}$ In this study, the antioxidant and hepatoprotective effect of honey against Antitubercular drugs induced hepatotoxicity in rats was shown by measuring antioxidant enzyme activities. 
Varied chemical composition of honey makes it difficult to assign its hepatoprotective property to one of its constituent chemical. Hence more detailed experimental and later on clinical studies are required with different isolated compounds present in honey to confirm its hepatoprotective action against Antitubercular drugs induced hepatotoxicity.

This study reveals that honey significantly prevent as well as reverse hepatotoxicity induced by antitubercular drugs in rats. Thus it can be concluded that honey by way of inhibiting lipid peroxidation and by increasing antioxidant defense mechanism has a significant hepatoprotective action.

\section{ACKNOWLEDGEMENTS}

We are thankful to Dr. V. V. Wase, Dean, S. R. T. R. Govt. Medical College, Ambajogai, for allowing us to carry out this study. We are also thankful to Dr. Mogarekar, Ranjeet Ambad, Dept. of Biochemistry and Dr. Giriji, Dr. Zadke, Dept. of Pathology for their valuable guidance and help to carry out this study.

Funding: No funding sources

Competing interests: None declared

Ethical approval: This study was approved by the Institutional Animal Ethics Committee

\section{REFERENCES}

1. Sapakal VD, Ghadge RV, Adnaik RS, Naikwade NS, Magdum CS. Comparative hepatoprotective activity of Liv-52 and livomyn against carbon tetrachloride induced hepatic injury in rats. Inter $\mathbf{J}$ Green Pharma 2008;2:79-82.

2. Col AC Anand, Lt Col AK Seth, Lt Col M Paul. Risk Factors of Hepatotoxicity During Antituberculosis Treatment. MJAFI 2006;62:45-9.

3. Sodhi CP, Rana SV, Mehta SK, Vaiphei K, Attari S, Mehta S. Study of oxidative-stress in isoniazidrifampicin induced hepatic injury in young rats. Drug Chem Toxicol 1997;20:255-69.

4. Zumla A, Lulat A. Honey--a remedy rediscovered. J R Soc Med 1989;82:384-5.

5. Zaghlout AA, EL-Shattawy HH, Kassem AA, Ibrahim EA, Reddy IK, Khan MA. Honey a prospective antibiotic extraction formulation and stability. Pharmazie 2001;56:643-7.
6. Jeffrey AE, Echazarreta CM. Medical uses of honey. Rev Biomed 1996;7:43-9.

7. Al-Waili NS. Therapeutic and prophylactic effects of crude on chronic seborrheic dermatitis and dandruff. Eur Med J Med Res 2001;6:306-8.

8. Pérez E, Rodríguez-Malaver AJ, Vit P. Antioxidant capacity of Venezuelan honey in wistar rat homogenates. J Med Food 2006;9:510-6.

9. Al-Waili NS, Saloom KY, Al-Waili TN. Influence of various diet regimens on deterioration of hepatic function and hematological parameters following CCl4: a potential protective role of natural honey. Nat Prod Res 2006;20:1258-64.

10. Khadr ME, Mahdy KA, El-Shamy KA, Morsy FA. Antioxidant activity and hepatoprotective potential of black seed, honey and silymarin on experimental liver injuries induced by $\mathrm{CCl} 4$ in rats. J Applied Sci 2007:7:3909-17.

11. Ghosh MN. Fundamentals of experimental pharmacology, Scientific book agency, Calcutta, 1984:155.

12. Mahgoub AA, el-Medany AH, Hagar HH, Sabah DM. Protective effect of natural honey against acetic acid-induced colitis in rats. Trop Gastroenterol 2002;23:82-7.

13. Reitman S, Frankel S. In vitro determination of transaminase activity in serum. Am J of Clin Pathol 1957;28:56-60.

14. Pasha KV, Sadasivadu B. Intracellular content of thiol compounds, thiobarbituric acid reactive substances and gamma-glutamyl transpeptidase in rat brain during anoxia. Nurosci Lett 1984;46:20914.

15. Marklund S, Marklund G (1974): Involvement of the superoxide anion radical in the autoxidation of pyrogallol and a convenient assay for superoxide dismutase, Eur J Biochem, 47: 469-74.

16. Sherlock S, Dooley J, editors. Drugs and Liver. In: Diseases of the Liver and Biliary System, 11th Edition. Blackwell Science: Oxford, UK; Malden, MA; 2002:335-63.

17. Cherubini A, Vigna GB, Zuliani G, Ruggiero C, Senin U, Fellin R. Role of antioxidants in atherosclerosis: epidemiological and clinical update. Curr Pharm Des 2005;11:2017-32.

18. Gheldof N, Wang XH, Engeseth NJ. Identification and quantification of antioxidant components of honeys from various floral sources. J Agric Food Chem 2002;50:5870-7.

doi:10.5455/2319-2003.ijbcp20130311

Cite this article as: Chandane RD, Jaju JB,

Ghadlinge MS, Bhosale RR, Chandrakapure AR.

Effect of honey on hepatotoxicity induced by antitubercular drugs in albino rats. Int J Basic Clin Pharmacol 2013;2:177-81. 